IRA International Journal of Management \& Social Sciences ISSN 2455-2267

Vol. 14, Issue 02 (Special Issue) pg. 177-181.

International Conference on Wellbeing: Lifespan Perspectives $\Xi^{\circ}$ Practices for Sustainable

Communities, 2019.

\title{
Social and Cultural Impacts of Resettlement Programme: Case study of Mendrelgang Gewog, Tsirang Dzongkhag
}

Tanka Nath Dhital

Department of Political Science and Sociology, Sherubtse College, Royal University of Bhutan, Bhutan.

DOI: $10.21013 /$ jmss.v14.n2sp.p18

(c) Authors.

Type of Review: Peer Reviewed under the Responsibility of the conference's Scientific Committee.

Disclaimer: The copyright to this work is retained by the authorship. This work contains the opinions $\Xi^{\circ}$ views of the authorship solely and the same are not the views or opinions of the IRA. IRA disclaims of any harm or loss caused due to the published content to any party. 


\begin{abstract}
This article will critically look at social and cultural impacts of resettlement programme, manifest and latent function of resettlement programme which has gradually helped in terms of diffusion of cultural and had let to the social integration of people of Mendrelgang geowg under Tsirang Dzongkhag. Previously Mendrelgang gewog have a dominant population of Lhotshampa speaking the Nepali language. Now with the introduction of resettlement programme we have almost people from twenty dzongkhag which comprise of Lhotshampas, Ngalops, sharshops, Kheng and Brokpa and all. This different ethnic population has its unique language, cultural, beliefs and practices. So because of this, we have heterogeneity of population in one particular gewog (District). This heterogeneity of population has slowly helped in terms of diffusion of different culture among the different ethnic people. So this diffusion of culture and cultural traits has reduced the sense of Ethnocentrism among different communities and brought cultural and social inclusiveness. Despite the difference that they have in terms of culture, beliefs, practice, race and ethnicity. People of Mendregang gewog are working together to maintain social solidarity through collective action. This in return helped them to understand and respect each other culture. So because of this people of Mendrelgang are having unity in diversity. This is how people of Mendrelgang are contributing towards building a happy nation and contributing to Gross National Happiness.
\end{abstract}

KEYWORDS: Diffusion, Ethnocentrism, cultural shock, Unity and Diversity, Integration

\title{
1. INTRODUCTION
}

Resettlement is a voluntary or involuntary movement of a large number of people from one place (which is usually the original settlement) to another (which is a new settlement), and this movement is not without consequence (Akpanudoedehe, 2010). It is the spontaneous or planned movement of people from their original settlement sites to resettle in a new one where they have to adapt to the biophysical, social and administrative system of the new environment. During the relocation or adaptation process, APs may face physical and mental stress (Woube, 2005). Resettlement can either be forced or voluntary (Jubril, 1990).

Nigeria and indeed Africa is witnessing massive resettlement since the 1960s (Olawepo, 2008). Major causes of this displacement include among others socio-political upheavals like wars, civil unrest, religious and ethnic crisis; natural disasters such as droughts, famines, floods, and from planned resettlement scheme for agriculture, urban resettlement etc. Dam projects like Kainji Dam in Nigeria are also responsible for the movement of people (Cernea, 1993; Ayeni, Roder \& Ayanda, 1994; Olawepo, 2008).

Resettlement programme in Bhutan was initiated by His Majesty the Fourth Druk Gyalpo to granting Kidu to the landless, near landless, and households dependent on shifting cultivation (tseri/pangzhing) under the resettlement program which commenced in 1997. Since then, nine phases were implemented in five Dzongkhags namely Dagana, Samdrup Jongkhar, Tsirang, Sarpang and Samtse resulting in the resettlement of 4,600 households.

According to the reports of Population and Housing Census of Bhutan (PHCB) 2017, which Prime Minister Tshering Tobgay released yesterday, Bhutan total population was 735,553 which comprises of:

1. Ngalops, people of Tibetan origin who migrated to Bhutan as early as the ninth century. The Ngalop introduced Tibetan culture and Buddhism to Bhutan and were the dominant political and cultural element in modern Bhutan. They speak Dzongkha which is the national language of Bhutan.

2. The Sharchop (meaning "easterner"), are the populations of mixed Tibetan, South Asian and Southeast Asian. Most Sharchop speak Tshangla, a Tibeto-Burman language.

3. Lhotshampa (meaning "southerners"), the culture has historical links to Nepal, and speaks the same language as the Gorkha people with few differences, but has become an individual ethnicity over time. The Lhotshampa are generally classified as Hindus but they consist of groups like Brahmins, Chetheri, Rai, Limbu, Gurung and Tamang.

4. Khengpa is ethnic group found in Zhemgang and another district of Bhutan. They have their own dialects called khenga. They follow extended Tibetan religion.

5. The Brokpa people are semi-nomadic, yak herders who have lived largely in isolation since arriving in Bhutan. Brokpa's language and customs are very unique to other Bhutanese ethnic groups.

The purpose of this study, therefore, is to investigate the Social and Cultural Impacts of Resettlement programme of Mendrelgang Gewog, Tsirang Dzongkhag, Bhutan. Further, this study would examine the effect of resettlement on 
social and cultural activities like social integration, reduce the sense of ethnocentrism and helps in community building

\section{THE METHODOLOGY}

On the basis of the above objectives, this research is based on the primary sources of data collection. The research is also depending on primary data collection through a narrative interview with the people. The respondents will be selected through random sampling. Unstructured questionnaire was also used during the interview.

\subsection{Problem Statement}

- Social and Cultural Impacts

- Cultural diffusion

- Ethnocentrism

- Community building

\subsection{Central Research Question}

- Social and Cultural Impacts of Resettlement programme

\subsection{Sub Questions \\ - How this programme helps in reducing the sense of ethnocentrism? \\ - How do these help in community building?}

\section{LITERATURE REVIEW}

Resettlement and Socio-economic Dynamics Resettlement occurs frequently in real life and there is no doubt that it causes major economic losses and cultural disruption. There are convincing statistics that show that involuntary resettlement is not a minor or secondary problem. Dams and reservoir projects such an as Gezhouba Dam in China and Dienjanakov.

Reservoir in India displaced 383 and 90,000 people respectively. The magnitude of displacement varies according to population density and ecological conditions (Cernea, 1990). The socio-cultural cum economic implications of resettlement in developed and developing countries have also been reported by Viser (1972), Lightfoot (1979), Afolayan (1987), Jibril (1990, 2006), Olawepo (2000, 2006), and Johnson (2009). The socio-political and psychological cost of involuntary resettlement has been unavoidably high and in some cases irreversible (Jibril, 2006; Olawepo, 2008).

\section{EFFORTS TO RESETTLE PEOPLE OF MENDRELGANG GEWOG}

Landlessness is a main cause of poverty in rural areas in Bhutan. The majority of rural people depend on agriculture and agriculture-related activities to make their living. In some dzongkhags, the landless were more prone to poverty because of dependency on landlords and inadequate arable land. So such living conditions forced landless people to look for alternatives to sustain the livelihood. So His Majesty the Fouth Druk Gyalpo granted land kidu to landless people with the vision (National Land Commission Secretariat, 2007)

1. To eradicate poverty

2. Provide land ownership to reduce dependency on landlords and shifting cultivation.

3. Increase self -sufficiency

4. Reduce economic inequality ( reduce the gap between rich and poor)

5. Creating and enhancing income generation opportunities through agricultural production.

6. Empower and uplift landless people

\section{DISCUSSION OF FINDINGS}

This article takes a critical look at the Social and Cultural Impacts of Resettlement programme: a Case study of Mendrelgang Gewog, Tsirang Dzongkhag, Bhutan. The manifest and latent function of the resettlement programme and the diffusion of cultural practice in Mendrelgang geowg under Tsirang Dzongkha through Re-settlement Programme. Tsirang Dzongkhag has a total projected population of 19,933 in 2009 out of which 10,107 are male and 9,825 are female. (National Statistics Bureau, 2010)

Mendrelgang gewog have a dominant population of Lhotshampa speaking the Nepali language. Now with the introduction of resettlement programme now it has almost people from twenty dzongkhags which comprise of Lhotshampas, Ngalops, sharshops, Kheng and Brokpa and so on. So because of that, we have heterogeneity of 
population in one particular gewog. So this heterogeneity of population has helped in terms of diffusion of different culture among the people. This diffusion has reduced the sense of Ethnocentrism among different communities and brought cultural and social inclusiveness.

My findings do not support Ayanda (1988), Cernea (1991a, 1993), Jackson and Sleigh (2000), and Olawepo (2008). They argued that resettlement tears apart the social fabric of existing communities and disrupt the occupation of the indigenous population.

Jubril (2006) and Olawepo (2008) observed that resettlement causes not only occupational dislocation of the APs, but affects the socio-political and psychological lives, and the impact has been unavoidably high and in some instances irreversible.

But my findings indicate that there is a significant relationship between resettlement and the community collectiveness which includes community services during birth and death, labour exchange, community engagement during religious festivals and marriage ceremonies and Community services in building Public Property and finally people come together towards building a happy nation and contributing to Gross National Happiness.

\section{a. Community services during birth and death}

Lotshampa have their own way of conducting rites and ritual during birth and death in the family. But in the first phrase this heterogeneity of population experienced cultural shock but gradually with the passage of time, there is diffusion of culture which leads to reduce the sense of ethnocentrism. Despite having difference during the time birth and death in a family, the local people of the community visit each other and render their moral support, offer cash as semso and exchange of goods and services according to cultural practices and beliefs of the deceased family. This practice is based on the principle of community reciprocity. During that time people tend to forget their individual interest and align themselves with group action. This is still continued today, thus maintaining the community collectiveness.

\section{b. The Labor Exchange System in the Gewog}

People of Mendrelgang mostly depends on agriculture production and activities. Earlier people did not exchange labour among other communities. But now increase in rural-urban migration and more enrolment in the school people faced a labor shortage. So because of this people realized that they need to come together to overcome this problem irrespective of differences. Individual household support each other on the basis reciprocity and exchange of labour, farm machinery such as oxen and power tillers etc. These practices not only exchange workforce and farm machinery but also gave them a platform to discuss the problem and help to socialize each other.

\section{c. Community engagement during religious festivals}

The gewog consist of heterogeneity of population having different religious and festivals practices. At the beginning of the resettlement programme, they experienced cultural shock and used to criticize each other and led to conflict and contradiction. Now people actively participate in different religious festivals like Tshechu and Dassera and contribute in cash and provided necessary supports.

\section{d. Community services in building Public Property}

When it comes to building public property people come together in building and maintaining a public property like building footpaths, cleaning footpaths, maintaining farm roads and render their free labour takes ownership towards public property. This practice is still continued today, thus make gewog a better place for everyone.

\section{e. Political Participation}

When it comes to political participations people tend to forget their heterogeneity and come to together to elect the best candidate who will bring change for the Gewog and nation at large.

\section{CONCLUSION}

The findings from the study show that the resettlement programme have helped to diffuse the culture, beliefs, language and religion. People are working together to maintain social solidarity through collective action. This in return helped them to understand and respect each other's culture. So because of this people are having unity in diversity. This is how people of Mendrelgang are contributing towards building a happy nation and contributing to Gross National Happiness. 


\section{References}

1. Afolayam, A. A.. (1987). The Sasa Resettlement Project: A Study in Problems of Relocation. Habitat International, 2; 43-57.

2. Akpanudoedehe, J. J. (2010). Socio-economic and Cultural Impacts of Resettlement on Bakassi People of Cross River State Nigeria. Unpublished Seminar Paper Presented at the Department of Sociology University of Calabar, Calabar Nigeria.

3. Ayeni, S. O., Roder, W. \& Ayanda, J. O.. (1994). Kainji Lake Experience in Nigeria. In M. M. Cernea (ed) Sociology, Anthropology and Development: Washington D. C. World Bank.

4. Cernea, M. M.. (1990). Population Displacement and Water Resources Development: Current Practice, Issues and Policy Responses Paper Presented at the Third Export Group Workshop on River/Lake Basis Approaches to Environmentally Sound Management of Water Resources, Otsu, Japan.

5. Cernea, M. M.. (1993). Africa Population Resettlement in A Global Context. In C. Cook (ed).

6. Agba, A. M. Ogaboh; Akpanudoedehe, J. J.; Ushie, E. M./Studies in Sociology of Science Vol.1 No.2 2010

7. Jibril, I. U.. (1990). Resettlement Problems in Usman Town of Nigeria's New Federal Capital Territory. Unpublished M.Sc. Thesis of Bayero University, Kano, Nigeria.

8. Johnson, K.. (2009). Scars of Bakassi. The Nation. Online available at: http://the nation onlineng.net/wb2/articles/25/212/1/scars-of-Bakassi. Retrieved 16/5/2010.

9. Lightfoot, R.. (1979). Planning Reservoir Related Resettlement Programme in North-East Thailand. Journal of Tropical Geography. 48, 47-57.

10. National Land Commission Secretariat (2007). Retrieved from https:/www.nlcs.gov.bt

11. National Statistics Bureau (2010). Retrieved from Website: www.nsb.gov.bt

12. Olawepo, R. A.. (2008). Resettlement and Dynamics of Rural Change in Jebba Lake Basin, Nigeria.

13. Population and Housing Census of Bhutan (2017). Retrieved from https:/www.kuenselonline.com/bhutans-population. 